№ 1. - 160 с. 3. Бондарчук Н. Я. Належні норми рухових можливостей студентів Ужгородського національного університету / Н. Бондарчук, В. Чернов, Л. Ляховець // Спортивний вісник Придніпров’я: [науково-практичний журнал]. - 2010. - № 2. - С. 157159. 4. Бойко Д. В. Сучасний стан та перспективні напрямки вдосконалення фізичного виховання студентів ВНЗ України III-IV рівнів акредитації / Д. В. Бойко // Педагогіка, психологія та медико-біологічні проблеми фізичного виховання і спорту. - Харків : ХДАДМ (ХХПІ), 2012. - № 1. - С. 22-25. 5. Коник Г. А. Современные тенденции организации физического воспитания студентов / Г. А. Коник, В. А. Темченко, Т. Е. Усова // Физическое воспитание студентов творческих специальностей. - 2009. - № 4. - С. 68-74. 6. Малімон О. О. Диференційований підхід у процесі фізичного виховання студентів: автореф. дис. на здобуття наук. ступеня канд. наук з фіз. виховання і спорту: спец. 24.00.02 / О. О. Малімон. - Луцьк, 1999. - 19 с. 7. Попрошаев А. В. Приемущества секционной формы организации учебного процесса по дисциплине «Физическое воспитание» / А. В. Попрошаев, В. С. Мунтян // Физическое воспитание студентов: [научный журнал]. - Харьков, ХОВНОКУ-ХДАДМ, 2011. - № 4. - С. 67-71. 8. Сичов С. О. Прилучення студентської молоді до цінностей фізичної культури в процесі атлетичного тренування / С. О. Сичов //Педагогіка, психологія та медико-біологічні проблеми фізичного виховання і спорту. - Харків : ХДАДМ (ХХПІ), 2011. - №1. - С. 115-118. 9. Церковная Е. В. Биологический возраст и темпы старения студентов с разным уровнем двигательной активности / Е. В. Церковная, А. Л. Нефедова, В.Н.Осипов, О. А. Миргород // Физическое воспитание студентов: [научный журнал]. - Харьков, ХОВНОКУ-ХДАДМ, 2011. - № 1. C. 130-133. 10. Lubysheva L. I. The concept of sports training: methodology development and technology implementation // Physical culture: education, education and training. - 1996. - № 1. P. 11-17.

УДК $378+613$

Наталія Гуменко, Тарас Андріанов, Валентина Марчик

\title{
РУХОВА АКТИВНІСТЬ І ПРАВИЛЬНЕ ХАРЧУВАННЯ У ФОРМУВАННІ ЗДОРОВОГО СПОСОБУ ЖИТТЯ СТУДЕНТСЬКОЇ МОЛОДІ
}

Гуменко Н. Ф., Андріанов Т. В., Марчик В. I. Рухова активність і правильне харчування у формуванні здорового способу життя студентської молоді.

Пріоритетність фізичного виховання у процесі виховання дітей, закріплення здорового способу життя в молоді та його підтримання у зрілому віці повинно бути важливою державною політикою. Рухова активність та правильне харчування є запорукою гармонійного фізичного розвитку, нормалізації ваги, наявності енергії й почуття здоров'я. Використання електронних ресурсів сприяє підвищенню усвідомленості й зацікавленості студентів у питаннях формування навичок здорового способу життя i, як наслідок, рівня фізичної підготовленості.

Ключові слова: здоровий спосіб життя, рухова активність, правильне харчування, студент, електронний ресурс.

Гуменко Н. Ф., Андрианов Т. В., Марчик В. И. Двигательная активность и правильное питание в формировании здорового образа жизни студенческой молодежи.

Приоритетность физического воспитания в процессе воспитания детей, закрепление 
здорового образа жизни у молодежи и его поддержание в зрелом возрасте должно быть важной государственной политикой. Двигательная активность и правильное питание является залогом гармоничного физического развития, нормализации веса, наличия энергии и чувства здоровья. Использование электронных ресурсов способствует повышению осознанности и заинтересованности студентов в вопросах формирования навыков здорового образа жизни и, как следствие, уровня физической подготовленности.

Ключевые слова: здоровый образ жизни, двигательная активность, правильное питание, студент, электронный ресурс.

Humenko N. F. Andrianov T. V., Marchyk V. I. Physical activity and well-balanced nutrition in forming healthy lifestyle of students.

The priority of physical education in the upbringing of children, the support of healthy lifestyle among young people and its maintenance in adulthood should be important public policy. Physical activity and proper nutrition is the key to harmonious physical development, weight normalization, energy and health. The use of electronic resources contributes to the awareness and commitment of students when it comes to habit formation of healthy lifestyle and as a consequence of this the level of physical fitness.

Key words: healthy lifestyle, physical activity, well-balanced nutrition, student, electronic resource.

На сучасному етапі в дитячому та молодіжному середовищі набуває поширення малорухомий спосіб життя (комп'ютери, електронні ігри, перегляд телесеріалів тощо) і все більше переважають пасивні форми дозвілля, ризикована поведінка та різні форми залежності: алкоголь, наркотики, тютюнопаління i, як наслідок, зростають антигромадські вияви. У студентські роки складається світогляд особистості як основи майбутньої професійної діяльності, тому формування цінностей, норм і зразків поведінки здорового способу життя набуває особливого значення.

А. Титаренко зазначає, що у зв'язку з низкою сучасних проблем фізичне виховання повинно стати одним із пріоритетних напрямків освіти як важливий чинник у процесі формування навичок здорового способу життя підростаючого покоління [7, с. 176]. Підвищення знань студентів про здоров'я і чинники, що впливають на нього, та формування в них ціннісного ставлення до здорової поведінки допоможуть не тільки зберегти, а навіть покрщити показники здоров'я за період навчання у ВН3 [4, с. 79]. Визначено, що одним із найважливіших завдань навчального закладу $\epsilon$ пропагування, виховання i навчання здоровому способу життя студентів, які в майбутньому зможуть забезпечити високий професіоналізм, незалежно від економічних, соціальних і психологічних ситуацій [3, с. 57].

Доведено, що рухова активність є важливим чинником збереження працездатності, сприяє повній реалізації генетичної програми, збільшенню енергетичного потенціалу людини, функціональних ресурсів організму та тривалості життя. Автори наводить обсяги рухової активності, рекомендовані МОЗ України для окремих вікових категорій населення на тиждень: діти дошкільного віку - 21-28 год., діти шкільного віку - 14-21 год., студентська молодь - 10-14 год., службовці - 6-11 год., особи I зрілого віку - 8-12 год., особи II зрілого віку - 7-10 год., особи похилого віку - 5-6 год. [6, с. 90].

Недостатня культура правильного споживання харчових продуктів призвела до того, що від ожиріння в Україні страждає кожний восьмий чоловік і кожна шоста жінка, а надлишкову масу має майже половина населення [1, с. 224]. Під час дослідження

Педагогіка вищої та середної школи. - 2015. - Вип. 45 
раціонального харчування студентів установлено, що більша частина студентів $(64,7 \%)$ уважають своє харчування нераціональним. Автори виявили недостатню інформованість студентів у питаннях правильного харчування та зазначають про необхідність проведення просвітницької роботи [5, с. 83]. У дослідженні формування навичок здорового способу життя науковці показують, що 73,6 \% студентської молоді незалежно від віку, статі і місця проживання вважають залежним стан здоров'я від якості харчування [2, с. 119].

Mета статті полягає в обгрунтуванні значущості рухової активності і правильного харчування як складників здорового способу життя студентів і визначення шляхів реалізації окремих заходів у їх формуванні.

Стереотип поведінки людини в повсякденному житті з точки зору гігієни харчування, режиму, рухової активності тощо формується на основі аргументованих знань, які і $€$ мотивацією здорового способу життя. Цінності здорового способу життя можна охарактеризувати як позитивний результат ведення здорового способу життя, що забезпечує єдність фізичних, психічних, духовних і соціальних потреб особистості.

В останні роки з'явилися наукові праці, пов'язані з вивченням проблем здоров'я і здорового способу життя в рамках утворювального процесу професійної школи: обговорюються загальні питання здоров'я студентської молоді; здійснюється аналіз поширення алкоголізму й наркоманії в молодіжному середовищі; досліджується вплив різних чинників на формування здорового способу життя студентів; вивчається характер і рівень валеологічних знань студентів; здійснюється пошук умов і засобів формування здорового способу життя молоді.

Здоровий спосіб життя- це спосіб життєдіяльності людини, метою якого $є$ формування, збереження і зміцнення здоров'я, з виявом характерних рис у рівні культури суспільства й особи, місці здоров'я серед потреб людини, мотивації збереження і зміцнення здоров'я, настанові на довге здорове життя, навчанні засобам збереження і зміцнення здоров'я.

Сучасними медичними дослідженнями і клінічними експериментами доведено, що люди, які регулярно займаються фізичними вправами, зазнають певних «здорових» фізичних навантажень, значно рідше хворіють, мають високий імунітет, більш стійкі до впливу негативних чинників навколишнього середовища, фізичних і нервових перевантажень. Тобто практику регулярних фізичних навантажень і готовність до них організму також можна вважати одним із показників рівня фізичного розвитку і, відповідно, - фізичного здоров'я. Саме тому держава повинна докласти всіх зусиль, щоб усвідомлення важливості фізичної культури громадян набуло загального важливого значення, стало пріоритетним у процесі виховання дітей, закріплення здорового способу життя в молоді та підтримання його у зрілому віці.

У пропагандистській компанії здорового способу життя акцент звичайно припадає на підвищення рухової активності людини і недостатньо висвітлюється проблема харчування як складника здорового способу життя. Неправильне харчування викликає далекосяжні наслідки в когнітивному розвитку підлітка, що призводять зниження здатності до навчання, незадовільний концентрації уваги i, у підсумку, до зниження успішності.

Типова дієта підлітка охоплює солодкі газовані напої, піцу, чіпси і подібні продукти, містить недостатню кількість фруктів, овочів і продуктів із цільного зерна. Неправильне харчування призводить до того, що зростаючий організм не насичується необхідними поживними речовинами, і це може викликати такі проблеми, як: постійне запаморочення, підвищена стомлюваність, ослаблення імунної системи, руйнування зубів, проблеми 3 
суглобами, крихкість кісток і високий ризик переломів, низькорослість тощо.

Режим правильного харчування передбачає триразовий прийом їжі також два додаткових прийоми їжі 3 періодичністю у три години. За півгодини до прийому їжі рекомендується вжити одну склянку води. На сніданок, наприклад, може бути сто грамів кисломолочного сиру. Обід складається 3 трьох рівних частин: білки (м'ясо варене), вуглеводи (крупнозернисті каші), клітковина (салат зі свіжих овочів). Додаткові прийоми їжі можуть бути з одного продукту, таких як: склянка молока, варене яйце, сухофрукти, горіхи тощо. Денний прийом білків, вуглеводів і жирів бажано мати у такому співвідношенні: $40 \%-40 \%$ - $20 \%$. Жири рекомендується вживати не в чистому вигляді, а як складник продуктів харчування, рослинну олію за значущістю: нерафіновану оливкову, кунжутну, лляну, нерафіновану соняшникову як компонент до салатів. Правильне харчування передбачає виключення з раціону харчування смаженої їжі (заміна їх печеною), фастфудів і продуктів, що мають довготривалий термін зберігання.

Води організм повинен отримувати більше всього - 30 мл /кг ваги. Фрукти - овочі: п’ять порцій різних видів, приблизно 1 кг.

Зернові: шість порцій (порція - жменя): три порції каші і три шматочки хліба. Протеїни - одна порція: м'ясо (яловичина, кролик, куряче, риба), яйця, молоко. Жири: тверді жири рекомендується не більше 1-3 разів на тиждень. Солодощі: чим менше, тим краще, ідеально - заміна їх на сухофрукти.

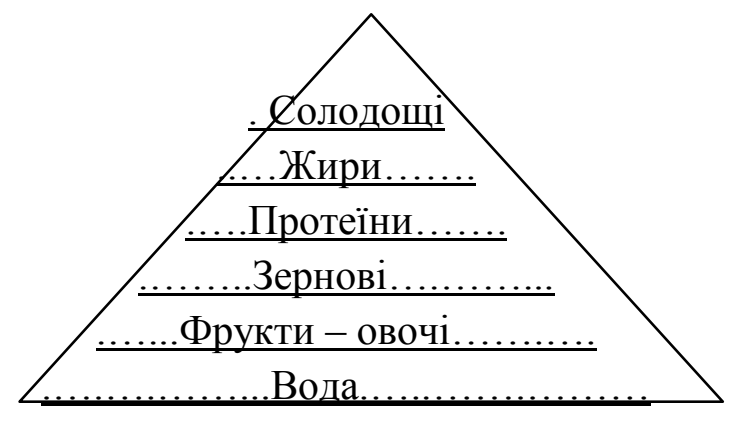

Піраміда пріоритетів

У забезпеченні поширення і вивчення теоретичного матеріалу з формування навичок здорового способу життя, а зокрема, рухової активності і правильного харчування у Криворізькому коледжі економіки та управління ДВНЗ «КНЕУ ім. В.Гетьмана» упроваджено використання групи в соціальній мережі «Циклова комісія 3 фізичного виховання». Студентам, за бажанням, було запропоновано нотування власних фізичних i психічних станів у динаміці змін під впливом фізичного навантаження й застосування збалансованого харчування, а самостійний аналіз таких змін було визначено як провідний критерій оцінювання успіхів у навчанні. На початку семестру студентам було поставлено завдання письмово розробити перспективний план власного фізичного вдосконалення, 3 самостійним визначенням мети та завдань, які мали б забезпечити динаміку позитивних змін результатів самоконтролю занять фізичними вправам порівняно з попереднім семестром. Аналіз отриманих результатів показав підвищення рівня фізичної і теоретичної підготовленості студентів, а також усвідомленості й зацікавленості в питаннях формування навичок здорового способу життя.

\section{Література}

1. Бенцак Р. Проблеми формування валеологічних цінностей здорового способу життя у студентів у процесі фізичного виховання / Роман Бенцак, Любов Покотило // 
Матеріали V Всеукраїнської науково-практичної конференції [«Теоретико-методичні основи організації фізичного виховання молоді»], (Львів, 15-17 травня 2014 року). - Львів : ЛНУ ім. Івана Франка, 2014. - С. 222-226. 2. Дідковський А. П. Проблема формування здорового способу життя студентської молоді / А. П. Дідковський, Г. П. Грибан, А. П. Денисовець // Матеріали V Всеукраїнської науково-практичної конференції [«Актуальні проблеми фізичного виховання студентів в умовах кредитно-модульної системи навчання»], (Дніпропетровськ, 10-11 квітня 2014 року).- Дніпропетровськ : ДНУ ім. Олеся Гончара, 2014. - С. 117-121. 3. Драчук В. Здоровий спосіб життя студентів як медико-біологічна, соціально-економічна та психолого-педагогічна категорія / В. Драчук, I. Заморський, О. Горошко, М. Ежнед // Матеріали XXI Всеукр. наук.-практ. конф. [«Валеологічна освіта в навчальних закладах України: стан, напрямки й перспективи розвитку»], (Кіровоград, 21-23 травня 2015 року). - Кіровоград : КДПУ ім. В. Винниченка, 2015. - С. 55-58. 4. Кузьменко I. Валеологічний самоаналіз підготовки у формуванні здорового способу життя студентів медичних коледжів/ Ірина Кузьменко // Матеріали XXI Всеукр. наук.практ. конф. [«Валеологічна освіта в навчальних закладах України: стан, напрямки й перспективи розвитку»], (Кіровоград, 21-23 травня 2015 року). - Кіровоград : КДПУ ім. В. Винниченка, 2015. - С. 76-80. 5. Мінжоріна I. Вивчення проблем харчування студентів / Ірина Мінжоріна, Ксенія Спиця // Матеріали XXI Всеукр. наук.-практ. конф. [«Валеологічна освіта в навчальних закладах України: стан, напрямки й перспективи розвитку»], (Кіровоград, 2123 травня 2015 року). - Кіровоград: КДПУ ім. В. Винниченка, 2015. - С. 80-84. 6. Омельченко Т. Г. Валеологічні аспекти впливу рухової активності на стан здоров'я населення України / Т. Г. Омельченко // Матеріали I Міжнар. наук.-практ. інтернет-конф. [«Актуальні проблеми медико-біологічного забезпечення фізичної культури, спорту та фізичної реабілітації»], (ХДАФК, 23 квітня 2015 року). - Харків : ХДАФК, 2015. - С. 88-92. 7. Титаренко А. А. Формирование здорового образа жизни у студенческой молодежи /А. А. Титаренко // Матеріали I Міжнар. наук.-практ. інтернет-конф. [«Актуальні проблеми медико-біологічного забезпечення фізичної культури, спорту та фізичної реабілітації»], (ХДАФК, 23 квітня 2015 року). - Харків : ХДАФК, 2015. - С. 173-176.

УДК 378

Ольга Дущенко

\section{ОНОВЛЕННЯ ВИЩОЇ ОСВІТИ НА ГРУНТІ ЗАСТОСУВАННЯ СУЧАСНИХ ІНТЕРНЕТ-ТЕХНОЛОГІЙ}

Дущенко О. С. Оновлення вищої освіти на грунті застосування сучасних інтернеттехнологій.

У статті розглядається проблема застосування сучасних інтернет-технологій у навчальному процесі. Пропонується класифікація інтернет-технологій в освіті, виокремлено позитивні та негативні сторони інтернет-технологій.

Ключові слова: інформаційні технології, інтернет-технології, класифікація інтернеттехнологій, переваги інтернет-технологій, недоліки інтернет-технологій.

Дущенко О. С. Обновление высшего образования на основе применения современных интернет-технологий.

В статье рассматривается проблема применения современных интернет-технологий в учебном процессе. Предлагается классификация интернет-технологий в образовании, 